\title{
STUDI KASUS DEKUBITUS PADA PENDERITA TIRAH BARING YANG DIRAWAT DI RSU ANUTAPURA PALU TAHUN 2018
}

\author{
Andi Muhammad Agus Salim Thamrin', Wijoyo Halim ${ }^{1 *}$, Mohamad Fandy ${ }^{1}$ \\ ${ }^{1}$ Program Studi Pendidikan Dokter, Fakultas Kedokteran Universitas Alkhairat, Jl. Diponegoro \\ No. 39 Palu 94221, Sulawesi Tengah, Indonesia \\ "Corresponding author: Telp: +628124245438 email: wijoyoneuro@gmail.com
}

\begin{abstract}
ABSTRAK
Dekubitus adalah kerusakan pada kulit dan jaringan dibawahnya karena kurangnya suplai darah akibat tekanan dalam waktu yang lama. Dekubitus mempunyai dampak tehadap kesehatan karena dapat memberikan kerugian bagi penderita, serta rumah sakit. Bahkan banyak ditemukan yang bisa menyebabkan kematian. Penelitian ini bertujuan untuk menggambarkan penyebab dan faktor - faktor resiko dekubitus pada penderita tirah baring di RSU Anutapura Palu pada tahun 2018. Jenis penelitian yang digunakan adalah kualitatif deskriptif dengan pendekatan studi kasus. Pengumpulan data dilakukan dengan metode consecutive sampling. Pada consecutive sampling, semua subjek yang ada dan memenuhi kriteria pemilihan dimasukkan dalam penelitian. Studi kasus pasien dekubitus pada perawatan tirah baring di RSU Anutapura Palu Tahun 2018 ditemukan faktor terbanyak adalah karena minimnya mobilisasi atau imobilisasi pasien yaitu 6 dari 6 (100\%). Faktor lain yaitu status gizi buruk 2 dari 6 pasien (33,3\%). Lansia 2 dari 6 pasien $(33,3 \%)$. Kelembaban 1 dari $6(18,7 \%)$. Ditarik kesimpulan bahwa faktor terbanyak pada kejadian ulkus dekubitus pada penderita tirah baring adalah mobilitas pasien atau imobilisasi. Faktor-faktor lain yang berpengaruh adalah status gizi, usia, kelembaban dan riwayat penyakit DM.
\end{abstract}

Kata Kunci : Dekubitus, faktor resiko dekubitus, tirah baring, penderita tirah baring.

\section{ABSTRACT}

Decubitus is damage to the skin and underlying tissue due to a lack of blood supply due to pressure for a long time. Dekubitus has an impact on health because it can provide harm to sufferers, as well as hospitals. In fact many are found that can cause death. This study aims to describe the causes and risk factors of pressure sores in bed rest patients in Anutapura Palu Hospital in 2018. The type of research used was descriptive qualitative with a case study approach. Data collection was done by consecutive sampling method. In consecutive sampling, all existing subjects and meeting selection criteria were included in the study. The case study of decubitus patients in bed rest treatment at Anutapura Palu Hospital in 2018 found the most factor was due to the lack of mobilization or immobilization of patients, namely 6 out of $6(100 \%)$. Other factors were poor nutritional status 2 of 6 patients (33.3\%). Elderly 2 out of 6 patients (33.3\%). Humidity 1 of 6 (18.7\%). The conclusion was drawn that the most factor in the incidence of pressure ulcers in bedridden patients is patient mobility or immobilization. Other factors that influence are nutritional status, age, humidity and DM history.

Keywords: Decubitus, risk factors for decubitus, bed rest, bed rest patients.

\section{PENDAHULUAN}

Tirah baring adalah perawatan dengan berbaringnya pasien di tempat tidur akibat ketidakmampuan melakukan gerakan/aktivitas. $^{1,2}$ Tirah baring menjadi perawatan untuk banyak kondisi medis termasuk stroke, gagal ginjal kronik, cedera tulang belakang, penyakit jantung 
kongestif, kanker, kehamilan dan pasca operasi. ${ }^{3,4}$ Perawatan tirah baring sangat penting untuk menghindari akibat yang dapat terjadi dari tirah baring. Salah satu perawatan tirah baring adalah mobilisasi, perawatan mobilisasi pada pasien tirah baring sangat berpengaruh dalam upaya pencegahan akibat yang dapat terjadi. Penelitian menunjukkan pasien dengan mobilisasi menurunkan terjadinya luka dekubitus. Perawatan lain adalah berubah posisi secara berulang/sering, pemberian cairan yang adekuat, nutrisi adekuat. Pemberian kasur dekubitus juga memberikan pengaruh terhadap perkembangan kulit dan menurunkan gejala. ${ }^{3,5,6}$ Tirah baring yang berlangsung lama dapat menyebabkan dampak yang negatif terhadap sistem tubuh pasien yaitu dapat menyebabkan kerusakan integritas kulit, seperti abrasi dan ulkus dekubitus. Selain itu tirah baring yang berkepanjangan dapat mempengaruhi sistem kardiovaskuler dan musukuloskeletal yaitu hilangnya kekuatan otot, kontraktur sendi dan hilangnya massa tulang. 6,7

Dekubitus adalah kerusakan pada kulit dan jaringan dibawahnya karena kurangnya suplai darah akibat tekanan dalam waktu yang lama. ${ }^{8}$ Faktor resiko terjadinya ulkus dekubitus pada pasien tirah baring adalah imobilitas seperti pada penderita stroke, kelembapan, status gizi yang buruk, lansia. Faktor lain yang dapat mempengaruhi adalah perawatan yang tidak adekuat. ${ }^{4}$ Komplikasi yang dapat terjadi bagi penderita luka dekubitus adalah terjadinya bakterimia yang dapat menyebabkan morbiditas dan mortalitas, sehingga biaya perawatan menjadi lebih tinggi. ${ }^{7} \quad$ Pengendalian penting untuk mencegah terjadinya luka dekubitus pada pasien tirah baring. Beberapa hal pengendalian seperti meminimalkan gesekan dan tekanan, menjaga kelembapan serta gizi yang cukup. ${ }^{11}$
Penelitian di Rumah Sakit Dr.Sardjito Yogyakarta sebesar $40 \%$ dari 40 pasien yang mengalami dekubitus akibat tirah baring. Penelitian di Rumah Sakit Dr.Moewardi Surakarta didapatkan angka kejadian ulkus dekubitus yaitu 38,18\%. Penelitian di RSUD Arifin Achmad Provinsi Riau tahun 2013 menguraikan pasien $>65$ tahun lebih rentan terkena ulkus dekubitus. Penelitian yang sama menunjukkan pasien berjenis kelamin perempuan lebih banyak terkena dekubitus dibanding laki-laki. ${ }^{4}$ Penelitian yang dilakukan pada populasi usia diatas 65 tahun dengan sampel 3.230 pasien didapatkan 214 pasien yang mengalami kekambuhan. Hampir setengah yang mengalami luka stage $2(46,8 \%)$ stage 1 $(6,1 \%)$ stage $3(7,0 \%)$ dan stage $4(3,5)$. Lokasi luka dekubitus paling umum terjadi pada sakrum $(39,2 \%)$, tumit $(19,6 \%)$ ischium $(14,6 \%)$ dan trochanter $(5,0 \%) .{ }^{10}$ Dalam sebuah studi melaporkan angka kematian ulkus dekubitus mencapai $22 \%$ sampai $68,8 \%$ karena komplikasi sistemik sekunder. ${ }^{11}$

Dekubitus akibat tirah baring merupakan masalah kesehatan karena banyak ditemukan yang bisa menyebabkan kematian. Memberikan kerugian bagi penderita, serta merugikan rumah sakit. Dengan diketahuinya penyebab serta factor-faktor yang dapat meningkatkan resiko terjadinya dekubitus pada pasien tirah baring, maka diharapkan angka kejadian dekubitus pada perawatan tirah baring dapat berkurang. Berdasar hal tersebut, maka perlu dilakukan penelitian mengenai studi kasus terhadap dekubitus pada penderita tirah baring yang dirawat di RSU Anutapura tahun 2018.

\section{METODOLOGI}

Jenis penelitian yang digunakan adalah kualitatif deskriptif. Desain penelitian dengan pendekatan studi kasus. Penelitian ini dilakukan pada bulan April sampai Juli 2018. Tempat penelitian dilaksanakan di 
ruang rawat inap RSU Anutapura Palu. Populasi penelitian adalah pasien dengan kejadian dekubitus yang dirawat dengan perawatan tirah baring di RSU Anutapura Palu.

Teknik pengambilan sampel dalam penelitian ini adalah consecutive sampling. Semua subjek yang ada dan memenuhi kriteria pemilihan dimasukkan dalam penelitian. Sampel penelitian adalah pasien dengan kejadian dekubitus yang dirawat dengan perawatan tirah baring di RSU Anutapura Palu yang memenuhi kriteria inklusi 1) Penderita yang dirawat dengan perawatan tirah baring di ruang perawatan RSU Anutapura Palu tahun 2018, 2) Pasien Laki-laki dan perempuan, 3) pasien yang berusia $\geq 18$ tahun, 4) Mempunyai kartu penduduk / pengenal, 5) Bersedia mengikuti penelitian tanpa paksaan setelah mendapat penjelasan. Pasien atau keluarga yang tidak dapat berkomunikasi dengan baik adalah kriteria eksklusi. Analisis Data menggunakan kualitatif deskiptif berupa penyajian data.

\section{HASIL DAN PEMBAHASAN HASIL}

Subjek Penelitian 001

$\begin{array}{ll}\text { No. Responden } & : 13001 \\ \text { Usia } & : \text { 65 Tahun } \\ \text { Jenis Kelamin } & : \text { Laki - Laki } \\ \text { Status Gizi } & : \text { Gizi Kurang }\end{array}$

Tanggal Pemeriksaan : 28 April 2018

Pasien masuk dengan perawatan tirah baring dengan diagnosis gastritis akut. Pasien juga menderita gagal ginjal kronik yang sudah diderita selama 4 bulan. Pada pemeriksaan status gizi berdasar LLA didapatkan hasil pasien mengalami status gizi kurang. Keluarga mengatakan pasien sangat sulit untuk diberi makan karena pasien sudah tidak memiliki selera makan. Keluarga juga mengatakan pasien sangat jarang melakukan aktivitas di rumah maupun diluar, hanya terus menerus berbaring di tempat tidur. Pasien sadar namun untuk melakukan aktivitas bisa dikatakan sangat minimal. Pasien pertama kali terkena dekubitus saat di rumah, namun luka semakin buruk saat di Rumah Sakit akibat tekanan yang secara terus menerus karena pasien terus berbaring serta jarang melakukan mobilisasi. Masih menurut keluarga, pasien sangat sulit dilakukan mobilisasi karena pasien seringkali marah ketika ingin dibangunkan ataupun digerakkan. Pasien memiliki riwayat merokok dan meminum minuman keras. Pasien mengalami luka dekubitus dibagian tulang dekat bokong.

Subjek Penelitian 002

No. Responden $\quad: 11002$

Usia : 31 Tahun

Jenis Kelamin $\quad$ : Laki - Laki

Status Gizi : : Gizi Baik

Tanggal Pemeriksaan : 07 Mei 2018

Pasien sadar masuk dengan perawatan tirah baring dengan diagnosis cefalgia kronik. Pasien juga menderita spondylitis. Menurut keluarga, sebelumnya pasien telah tirah baring di rumah selama 4 bulan dan terjadi kemerahan dibagian tulang belakang yang menonjol, kemudian pasien masuk di rumah sakit dan melakukan tirah baring dalam $1-4$ hari bagian kemerahan tersebut menjadi luka. Pasien memiliki status gizi baik berdasarkan pengukuran LLA. Menurut keluarga, pasien tidak dilakukan mobilisasi ataupun pemberitahuan untuk selalu dilakukan mobilisasi.

Subjek Penelitian 003

No. Responden : : 12003

Usia : 61 Tahun

Jenis Kelamin $\quad$ : Laki - Laki

Status Gizi : : Gizi Baik

Tanggal Pemeriksaan : 09 Mei 2018

Pasien masuk dengan perawatan tirah baring akibat kecelakaan lalu lintas mengakibatkan terjadi trauma capitis 
serta patah tulang kaki kiri. Pasien awalnya dirawat di ICU selama 22 hari kemudian dipindahkan ke ruang perawatan saraf. Menurut keluarga luka pertama kali muncul pada saat di ICU beberapa hari sebelum dipindahkan ke ruang perawatan saraf. Meskipun sadar, pasien sangat sulit untuk melakukan mobilisasi ataupun dimobilisasi karena pasien merasa nyeri jika bergerak ataupun digerakkan akibat patah tulang yang dialami pasien. Pasien memiliki status gizi baik berdasarkan pengukuran LLA. Ulkus dekubitus muncul di daerah tulang dekat bokong.

Subjek Penelitian 004

$\begin{array}{ll}\text { No. Responden } & : 12004 \\ \text { Usia } & : 40 \text { Tahun } \\ \text { Jenis Kelamin } & : \text { Laki - Laki } \\ \text { Status Gizi } & \text { : Gizi Kurang }\end{array}$

Tanggal Pemeriksaan : 06 Juni 2018

Pasien sadar masuk dengan perawatan tirah baring dengan diagnosis selulitis. Pasien memiliki riwayat DM. Pasien mengeluhkan nyeri hebat dan sulit tidur. Pasien memiliki status gizi kurang berdasarkan LLA. Pasien merasa sulit melakukan mobilisasi karena nyeri hebat yang dirasakan. Luka dekubitus muncul di kaki sebelah kanan di bagian mata kaki dan bagian luar tumit kaki. Luka pertama kali muncul dihari 6-7 perawatan. Perawatan yang dilakukan adalah dengan mengupayakan mobilisasi pada pasien.

Subjek Penelitian 005

No. Responden : :23005

Usia :76 Tahun

Jenis Kelamin : Perempuan

Status Gizi : Gizi Kurang

Tanggal Pemeriksaan : 26 Juni 2018

Pasien tidak sadar masuk dengan perawatan tirah baring dengan diagnosis HS (hereditary spherocytosis) yaitu terjadinya kelainan sel darah merah. Pasien telah dirawat selama 5 hari di ICU. Pasien menderita dekubitus setelah terpaparnya pasien dengan air seni pasien tersebut. Luka dekubitus berada di bagian tulang dekat bokong.

Subjek Penelitian 006

No. Responden : : 11006

Usia : 18 Tahun

Jenis Kelamin : Laki - Laki

Status Gizi : Gizi Kurang

Tanggal Pemeriksaan : 02 Juli 2018

Pasien tidak sadar masuk dengan perawatan tirah baring dengan diagnosis DSS (Dengue Shock Syndrome Pasien telah dirawat dan tidak sadar selama 14 hari di ICU. Pasien juga tampak bengkak seluruh tubuh. Menurut keluarga luka dekubitus mulai muncul pada hari ke 7 perawatan. Luka muncul sangat mungkin karena tidak adanya mobilisasi pada pasien. Untuk posisi luka pasien berada di kulit bagian tulang dekat bokong.

\section{PEMBAHASAN}

Subjek penelitian 001 diketahui pasien jarang melakukan aktivitas diluar rumah atau lebih banyak berbaring di tempat tidur. Hal tersebut dapat menjadi faktor pemicu munculnya luka dekubitus karena terjadi tekanan secara terus menerus pada kulit akibat minimnya imobilisasi yang dilakukan pasien. Hal ini sejalan dengan penelitian yang dilakukan oleh Corrine tahun 2011 di Australia bahwa ada hubungan antara kejadian dekubitus dengan imobilisasi. Corrine menjelaskan semakin sedikit dilakukan pergerakan makan semakin beresiko seseorang menderita ulkus dekubitus. Status gizi buruk pasien dapat menjadi faktor yang bisa mempermudah terjadinya dekubitus. Hal ini sejalan dengan penelitian yang dilakukan oleh Baumgarten tahun 2006 di Amerika Serikat bahwa ada hubungan antara kejadian dekubitus dengan status gizi buruk. Serta menurut Corrine tahun 2011 Defisit nutrisi berkaitan dengan perkembangan luka dekubitus. Tingkat protein dan albumin yang rendah dapat 
mempengaruhi ketebalan dari ulkus, sedangkan kadar vitamin dan seng mempengaruhi tingkat penyembuhan luka. Riwayat merokok dan meminun minuman keras juga merupakan faktor yang dapat menyebabkan ulkus dekubitus yaitu menyebabkan terganggunya aliran darah.

Subjek penelitian 002 diketahui pasien telah tirah baring selama 4 bulan di rumah dimana pasien menderita cefalgia kronik dan spondylitis yang membuat pasien sulit bergerak. Hal tersebut adalah faktor utama munculnya ulkus dekubitus yaitu karena tekanan yang terjadi secara terus menerus pada kulit karena minimnya mobilisasi yang dilakukan pasien. Hal ini sejalan dengan penelitian yang dilakukan oleh Corrine pada tahun 2011 di Australia bahwa ada hubungan antara kejadian dekubitus dengan imobilisasi. Corrine menjelaskan semakin sedikit dilakukan pergerakan makan semakin beresiko seseorang menderita ulkus dekubitus.

Subjek penelitian 003 diketahui pasien mengalami kesulitan mobilisasi karena patah tulang yang dialami sehingga pasien tirah baring dengan posisi yang sama secara terus menerus sehingga menyebabkan tekanan secara terus menerus pada kulit. Hal ini sejalan dengan penelitian yang dilakukan oleh Corrine pada tahun 2011 di Australia bahwa ada hubungan antara kejadian dekubitus dengan imobilisasi. Corrine menjelaskan semakin sedikit dilakukan pergerakan maka semakin beresiko seseorang menderita ulkus dekubitus.

Subjek penelitian 004 diketahui pasien menderita selulitis dengan nyeri hebat, membuat pasien mengalami kesulitan mobilisasi sehingga pasien tirah baring dengan posisi yang sama dalam jangka waktu lama. Hal tersebut membuat tekanan secara terus menerus pada permukaan kulit. Hal ini sejalan dengan penelitian yang dilakukan oleh Corrine pada tahun 2011 di Australia bahwa ada hubungan antara kejadian dekubitus dengan imobilisasi. Diketahui pasien juga memiliki riwayat DM dimana kadar gula darah yang tinggi dapat menganggu aliran darah di kapiler kulit, sehingga rentan terkena ulkus dekubitus. Faktor lain yang dapat menyebabkan pasien mengalami ulkus dekubitus adalah status gizi yang kurang. Hal ini sejalan dengan penelitian yang dilakukan oleh Baumgarten pada tahun 2006 di Amerika Serikat bahwa ada hubungan antara kejadian dekubitus dengan status gizi buruk.

Subjek Penelitian 005 diketahui pasien mengalami ulkus dekubitus setelah terpaparnya kulit dengan air seni pasien. Hal tersebut dapat menjadi faktor penentu munculnya ulkus dekubitus pada pasien akibat dari faktor kelembaban. Hal ini sejalan dengan penelitian yang dilakukan oleh Arry Muji Astutik pada tahun 2015 di RSUD Tidar Magelang bahwa ada hubungan antara kejadian dekubitus dengan kelembaban. Serta menurut Dewandono tahun 2014 bahwa kulit yang lembab akan mengkontribusi kulit menjadi maserasi. Selain itu faktor usia juga dapat mempengaruhi terjadinya ulkus dekubitus. Hal ini sejalan dengan penelitian yang dilakukan oleh Levina Mutia di RSUD Arifin Achmad Riau tahun 2011-2013 bahwa ada hubungan kejadian dekubitus dengan usia. Pada usia dewasa hingga usia lanjut terjadi penurunan toleransi terhadap tekanan, pergerakan dan gaya gesek. Hal ini disebabkan oleh perubahan-perubahan pada kulit, seperti penurunan elastisitas dan vaskularisasi, kehilangan otot, penurunan kadar serum albumin, penurunan respon inflamatori. Jenis kelamin dapat menjadi faktor resiko terjadinya ulkus dekubitus, pada perempuan menopause terjadi penurunan kadar hormon estrogen dimana hormon estrogen berfungsi menjaga ketebalan epidermis kulit, sehingga kulit menjadi rentan mengalami ulserasi. 
Subjek Penelitian 006 diketahui pasien tidak sadar sehingga pasien tidak dapat memobilisasi dirinya. Maka pasien perlu untuk dilakukan intervensi untuk mencegah munculnya ulkus dekubitus. Namun hal tersebut tidak dilakukan sehingga faktor imobilisasi menjadi faktor penentu munculnya ulkus dekubitus pada pasien. Hal ini sejalan dengan penelitian yang dilakukan oleh Corrine pada tahun 2011 di Australia bahwa ada hubungan antara kejadian dekubitus dengan imobilisasi.

\section{KESIMPULAN}

Faktor terbanyak pada kejadian ulkus dekubitus pada penderita tirah baring adalah mobilitas pasien atau imobilisasi. Adapun faktor-faktor lain yang berpengaruh yaitu status gizi, usia, kelembaban dan riwayat DM.

\section{DAFTAR PUSTAKA}

1. Kristin, J.S. The Physiological Consequences of Bed Rest. Scholarship at Gettysburg College; 2007.

2. Farlex. Bed Rest; 2012 (Online) https://medical-

dictionary.thefreedictionary.com/bed+ rest

3. Topp, R. et all. The Effect of Bed Rest and Potential of Prehabilitation on Patients in the Intensive Care Unit. American Association of Critical Care Nurses (AACN); 2002.

4. Mutia, L. Profil Penderita Ulkus Dekubitus Yang Menjalani Tirah
Baring Di Ruang Rawat Inap Rsud Arifin Achmad Provinsi Riau Periode Januari 2011 - Desember 2013; 2013.

5. Rustina. Pengaruh Penggunaan Kasur Anti Dekubitus Terhadap Derajad Dekubitus pada Pasien Tirah Baring. Mahasiswa Program Studi S1 Keperawatan STIKES Kusuma Husada Surakarta; 2015.

6. Rosita, T. Mobilisasi dan Timbulnya Luka Tekan Pada Pasien Tirah Baring. (Online)

http://lib.ui.ac.id/naskahringkas/201608/S57634-Tita\%20Rosita.

7. Dittmier, K.D. Complications of Immobilization and Bed Rest. Canadian Family Physician; 2003.

8. Bowman, T. Preventing and Treating Pressure Sores A Guide For People With Spinal Cord Injuries. Spinal Cord Injury Ontario; 2015.

9. Nordvist, C. Pressure Sores: What You Needto Know (online). https://www.medicalnewstoday.com/a rticles/173972.php

10. Keelaghan, E. Prevalence of Pressure Ulcers on Hospital Admission Among Nursing Home Residents Transferred to The Hospital (online); 2008. Http://www.ncbi.nlm.nih.gov/pmc/arti cles/PMC2839543/

11. Miza, B. Ulkus Dekubitus dan Penatalaksanaan. Fakultas Kedokteran Universitas Syiah Kuala Bpk Rumah Sakit Dr. Zainoel Abidin Banda Aceh; 2015. 